\title{
Comparison of Magnetic Resonance
}

Cholangiopancreatography and Endoscopic Retrograde Cholangiopancreatography in Pancreaticobiliary Pathologies

\author{
Pankreatikobilier Patolojilerde Manyetik Rezonans Kolanjiopankreatografi ile
}

Endoskopik Retrograd Kolanjiopankreatografinin Karşılaştırılması

\author{
Zeyneb Büyük Değerli, Ömer Yılmaz, Fatma Dilek Gökharman, Uğur Koşar \\ Department Of Radiology, Ankara Education And Research Hospital, Ankara, Turkey
}

\begin{abstract}
The aim of this study was to determine the sensitivity and diagnostic contribution of magnetic resonance cholangiopancreatography (MRCP) in identifying pancreaticobiliary system pathologies and compare with endoscopic retrograde cholangiopancreatography (ERCP). ERCP is currently considered the gold standard for the evaluation of the pancreaticobiliary system. However, MRCP is a safe, non-invasive diagnostic alternative to ERCP. By the introduction of MRCP into clinical use, there has recently been a tendency of decrease especially in the number of ERCP evaluations performed only for diagnostic purposes. 51 patients were included in the study with clinical and laboratory findings suggestive of obstructive biliary tract pathology, but in whom the ultrasound and/or computerized tomography (CT) findings were inconclusive. Sensitivity, specificity, positive and negative predictive value of MRCP in the diagnosis of common bile duct stone, common bile duct dilatation, common bile duct strictures and intrahepatic bile duct (IHBD) dilatation were assessed. The sensitivity, specificity, and positive and negative predictive values of MRCP for the assessment of all biliary tract pathologies were $85.0 \%, 50.0 \%, 89.4 \%$, and $40.0 \%$, respectively. An increase in the experience of the MRCP examination and studies with larger series may provide the improvement in results; thus, an increase in diagnostic success may be established.
\end{abstract}

Keywords: MRCP, ERCP, biliary tract pathologies

Aplication: 06.06.2012 Accepted: 16.09.2012
Özet

Bu çalışmanın amacı pankreatikobilier sistem patolojilerinin tespitinde manyetik rezonans kolanjiopankreatografinin (MRCP) duyarlıı̆̆ı, tanıya katkısını belirlemek ve endoskopik retrograd kolanjiopankreatografi (ERCP) ile karşılaştırmaktır.ERCP günümüzde pankreatikobilier sisteminin değerlendirilmesi için halen altın standart olarak kabul edilir, ancak MRCP safra yollarının değerlendirilmesinde güvenli ve noninvaziv olması nedeniyle tanısal amaçlı ERCP'ye alternatif olabilir. MRCP'nin klinik kullanıma girmesiyle, son zamanlarda özellikle tanısal amaçlı ERCP incelemeleri sayısında azalma eğilimi görülmüştür. Klinik ve laboratuar bulguları ile obstrüktif safra yolu patolojisi düşünülen ancak ultrasonografi ve/veya bilgisayarlı tomografi bulguları kliniği açıklamada yetersiz kalan 51 hasta üzerinde yapılmıştır. Koledok taşı, koledok dilatasyonu, koledok darlıkları ve IHSY dilatasyonu tanısında MRCP'nin duyarlıık, özgüllük, pozitif prediktif değer ve negatif prediktif değeri değerlendirildi. MRCP'nin tüm safra yolları patolojilerinin değerlendirilmesinde duyarlılık, özgüllük, pozitif ve negatif prediktif değerleri sırasıyla, \%85.0, \%50.0, \%89.4 ve \%40.0 idi. MRCP deneyiminin artması ve geniş serili çalışmalarla sonuçlarda ilerleme sağlanacak ve tanısal başarı artacaktır.

Anahtar Kelimeler: MRCP, ERCP, safra yolu patolojileri

Başvuru Tarihi: 06.06.2012 Kabul Tarihi: 16.09.2012 


\section{Introduction}

Several disorders, including benign and malignant pathologies or trauma, may cause obstruction of the biliary tree. It is essential to determine the biliary tract and pancreatic duct pathologies in a patient presenting with obstructive jaundice. ERCP is currently considered the gold standard for the evaluation of the pancreaticobiliary system?' however, MRCP is a safe, non-invasive diagnostic alternative to ERCP for evaluation of the biliary tract.

The aim of the present study was to determine the sensitivity and diagnostic contribution of MRCP in identifying pancreaticobiliary system pathologies in patients referred with clinical and/or laboratory findings suggestive of biliary obstruction and compare these results with the results obtained by the invasive ERCP method.

\section{Materials and Methods}

The study was conducted in 51 patients with clinical and laboratory findings suggestive of obstructive biliary tract pathology, but in whom the ultrasound and/or CT findings were inconclusive. Patients were initially assessed by MRCP, then ERCP was performed on 20 patients in our hospital and on 31 patients in another center that were experienced in this field.

MRCP was performed following at least 6 hours of fasting in order to provide time for emptying of the stomach and duodenum, and filling of the gallbladder. MRCP was performed by a 1.5 Tesla MR device (Signa HDI; General Electric, Milwaukee, WI, USA), using an 8-channel phase-array upper body coil. First, axial two-dimensional Fast Imaging Employing Steady State Acquisition (2D FIESTA or balanced steady-state free precession [bSSFP]) sequence breath-hold images were obtained. Then, a coronal oblique T2-weighted 3D fast recovery fast spin echo-accelerated (FRFSE-XL) respiratory-triggered sequence followed by a breath-hold, thick-slab, T2-weighted single-shot fast spin-echo (SSFSE or half-Fourier singleshot turbo spin-echo [HASTE]) sequence were obtained. SSFSE (HASTE) thin-slice, coronal-oblique, breath-hold images were also obtained. The MR sequence parameters that were used during the examination are presented in Table 1.

Table 1: Magnetic resonance sequence parameters that were used during magnetic resonance cholangiopancreatography examination

\begin{tabular}{|c|c|c|c|c|}
\hline & $\begin{array}{c}\text { Axial 2D } \\
\text { FIESTA }\end{array}$ & $\begin{array}{l}\text { Coronal } \\
\text { oblique } \\
\text { T2-weight- } \\
\text { ed 3D } \\
\text { FRFSE-XL }\end{array}$ & $\begin{array}{c}\text { Thick-slab } \\
\text { T2-weight- } \\
\text { ed SSFSE } \\
\text { (HASTE) }\end{array}$ & $\begin{array}{l}\text { Thin slice, } \\
\text { coronal- } \\
\text { oblique } \\
\text { T2-weight- } \\
\text { ed SSFSE } \\
\text { (HASTE) }\end{array}$ \\
\hline TR (msec) & 4.2 & 3333 & 2757 & 676 \\
\hline TE (msec) & 1.9 & 728 & 1391 & 90 \\
\hline Matrix & $256 \times 320$ & $288 \times 288$ & $448 \times 256$ & $384 \times 224$ \\
\hline $\begin{array}{l}\text { Slice thick- } \\
\text { ness (mm) }\end{array}$ & 4.5 & 1.8 & 40 & 4 \\
\hline Gap (mm) & 1 & -0.9 & 0 & 0 \\
\hline $\mathrm{FOV}(\mathrm{cm})$ & $36 \times 36$ & $34 \times 34$ & $32 \times 32$ & $40 \times 40$ \\
\hline NEX & 1 & 0.75 & 1 & 1 \\
\hline \multicolumn{5}{|c|}{$\begin{array}{l}\text { 2D FIESTA: two-dimensional Fast Imaging Employing Steady State } \\
\text { Acquisition, FRFSE-XL: fast recovery fast spin echo-accelerated, } \\
\text { SSFSE: single-shot fast spin-echo, HASTE: half-Fourier single-shot } \\
\text { turbo spin-echo, TR: repetition time, TE: echo time, FOV: field of } \\
\text { view, NEX: number of excitations }\end{array}$} \\
\hline
\end{tabular}

No oral or intravenous contrast medium was used during imaging. The location and cause of the obstruction, IHBD diameter, common bile duct (choledochus) diameter and lumen, and pancreatic duct diameter were determined. Patients were classified with respect to cholangiographic and pancreatographic findings obtained by MRCP and ERCP. The study population was first classified according to the presence of bile duct stones. Patients with choledocholithiasis alone were classified as positive, while the patients without choledocholithiasis or patients with other common bile duct pathology were classified as negative. Then, patients were classified in terms of common bile duct stricture, common bile duct dilatation, and IHBD dilatation.

Statistical analyses were performed using Statistical Package for Social Sciences (SPSS) for Windows 16.0 (SPSS Inc., Chicago, IL, USA). Two techniques were compared in terms of sensitivity, specificity, and positive 
and negative predictive values. The groups were compared with the McNemar test.

\section{Results}

The mean age of the 51 patients, including 23 males $(45.1 \%)$ and 28 females (54.9\%), was 50.7 years (range, $15-83$ years).

The pancreatic duct was assessed in 7 of 51 patients evaluated by ERCP. Selective pancreatography was performed and the choledochus duct was not evaluated in 3 patients. So the study went on with 48 patients.

MRCP correctly identified 15 of 21 patients with bile stones and 23 of 27 patients without bile stones who were confirmed by ERCP There were 6 false-negative and 4 false-positive results for MRCP. The sensitivity, specificity, and positive and negative predictive values of MRCP in detecting bile duct stones were $71.4 \%$, $88.8 \%, 83.3 \%$, and $80.0 \%$, respectively.

MRCP correctly identified 2 of 7 patients with common bile duct strictures and 37 of 38 patients with no stricture of common bile duct who were confirmed by ERCP. There were 1 false-positive and 5 false-negative results for MRCP. The sensitivity, specificity, and positive and negative predictive values of MRCP in detecting common bile duct strictures were $28.5 \%, 97.3 \%, 66.7 \%$, and $90.2 \%$, respectively.

MRCP correctly identified 14 of 20 patients with common bile duct dilatation and 17 of 22 patients without common bile duct dilatation who were confirmed by ERCP. There were 5 false-positive and 6 false-negative results for MRCP. Proximal biliary tracts could not be evaluated by ERCP in 6 patients due to complete obstruction by stones. The sensitivity, specificity, and positive and negative predictive values of MRCP in detecting common bile duct dilatation were $70.0 \%, 77.2 \%$, $73.6 \%$, and $73.9 \%$, respectively.

MRCP correctly identified 22 of 26 patients with IHBD dilatation and 12 of 16 patients without IHBD dilatation who were confirmed by ERCP. There were 4 false-positive and 4 false-negative results for MRCP. The sensitivity, specificity, and positive and negative predictive values of MRCP in detecting IHBD dilatation were $84.6 \%$, $75.0 \%, 84.6 \%$, and $75.0 \%$, respectively.

Pancreatography was not performed in 44 of 51 patients evaluated by ERCP due to selective common bile duct cannulation. MRCP findings were correlated with ERCP in 4 of 7 patients. While the pancreatic duct was shown to be normal in remaining 3 patients by MRCP, narrowing and dilatation of the pancreatic duct, and cystic dilatation were demonstrated by ERCP. The MRCP findings were true-positive in 4 patients and false-negative in 3 patients.

The sensitivity, specificity, and positive and negative predictive values of MRCP for the assessment of all biliary tract pathologies were $85.0 \%, 50.0 \%, 89.4 \%$, and 40.0\% spectively (Table 2 ).

Table 2: The sensitivity, specificity, and positive and negative predictive values of MRCP for the assessment of all biliary tract pathologies

\begin{tabular}{|l|c|c|c|c|}
\hline & $\begin{array}{c}\text { Sensitivity } \\
\text { (\%) }\end{array}$ & $\begin{array}{c}\text { Specificity } \\
\text { (\%) }\end{array}$ & $\begin{array}{c}\text { Positive } \\
\text { predictive } \\
\text { value (\%) }\end{array}$ & $\begin{array}{c}\text { Negative } \\
\text { predictive } \\
\text { value (\%) }\end{array}$ \\
\hline $\begin{array}{l}\text { Bile duct } \\
\text { stones }\end{array}$ & 71.4 & 88.8 & 83.3 & 80.0 \\
\hline $\begin{array}{l}\text { Common } \\
\text { bile duct } \\
\text { stricture }\end{array}$ & 28.5 & 97.5 & 66.7 & 88.8 \\
\hline $\begin{array}{l}\text { Common } \\
\text { bile duct } \\
\text { dilatation }\end{array}$ & 70.0 & 77.2 & 73.6 & 73.9 \\
\hline $\begin{array}{l}\text { IHBD dila- } \\
\text { tation }\end{array}$ & 84.6 & 75.0 & 84.6 & 75.0 \\
\hline $\begin{array}{l}\text { Assess- } \\
\text { ment of all } \\
\text { biliary tract } \\
\text { pathologies }\end{array}$ & 85.0 & 50.0 & 89.4 & 40.0 \\
\hline \begin{tabular}{l} 
IHBD: Intrahepatic bile duct \\
\hline
\end{tabular} & & & \\
\hline
\end{tabular}

\section{Discussion}

Causes of biliary obstruction include stone disease, tumors, and iatrogenic biliary tract injuries sustained during 
gallbladder surgery (Figure 1-4). ERCP is still the gold standard imaging method for such biliary tract pathologies; however, ERCP continues to be a difficult procedure with failure rates ranging from 3\%-10\% due to its high dependency rates on user's skill and experience' ${ }^{1}$. By the introduction of MRCP into clinical use, there has recently been a tendency of decrease especially in the number of ERCP evaluations performed only for diagnostic purposes. MRCP is a non-invasive, safe alternative for evaluation of biliary tract pathologies when compared to ERCP. There is no risk of complications associated with pancreatic duct cannulation and the diagnostic efficiency of MRCP is similar in most of the pathologies. Moreover, MRCP can offer additional information about surrounding tissues because a cross-sectional evaluation can be performed.

Figure 1: Choledochus was wider than normal and a millimetric stone was noted at the distal end.

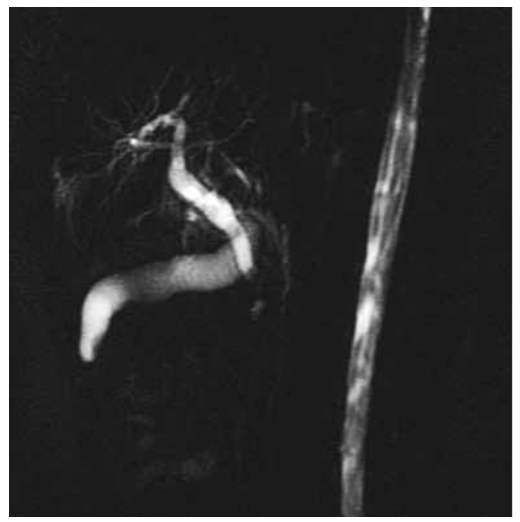

Figure 2: The appearance of biliary stone in the common bile duct at the cystic duct junction level. The intrahepatic bile duct and choledochus were wider than normal.

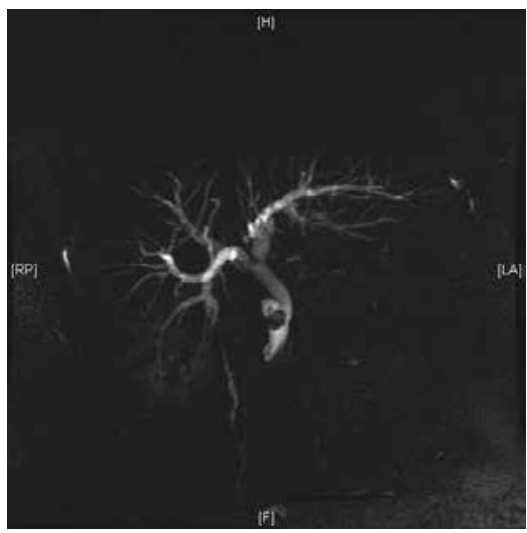

Figure 3: Appearance of dilated intrahepatic bile duct and no continuity of the intrahepatic bile duct and choledochus at the level of the portal hilus. The radiologic diagnosis was compatible with a Klatskin tumor

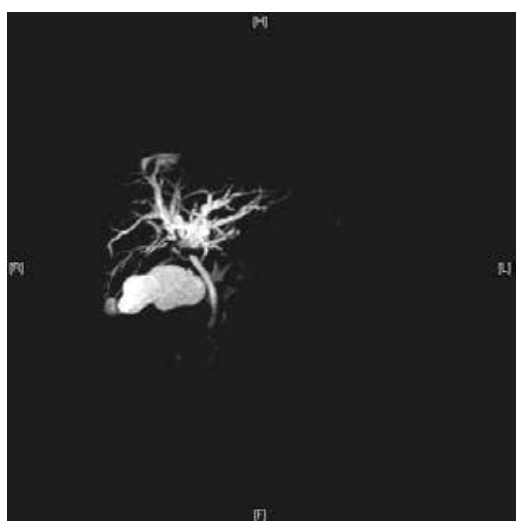

Figure 3: Common bile duct caliber suddenly reduced due to the mass causing the compression of the pancreatic head and the pancreatic duct appeared discontinued. Marked dilatation, including dilation of the side branches, was noted in the pancreatic duct extending through the body and tail of the pancreas

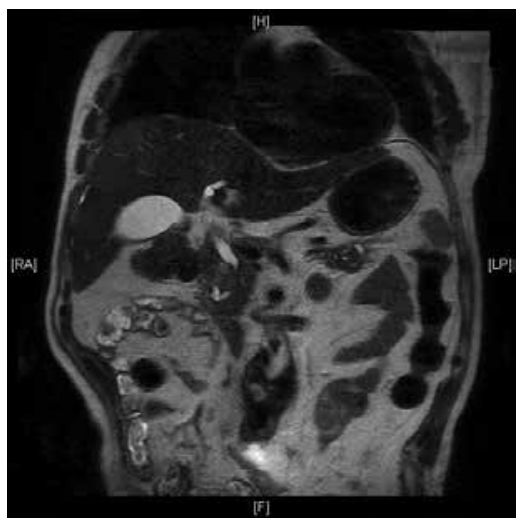

MRCP can provide imaging of the entire biliary tree proximal and distal to an obstruction, facilitating the diagnosis in cases in which the guidewire cannot be introduced due to stenosis and ERCP is non-diagnostic ${ }^{2-4}$. Offering a panoramic image, MRCP also provides detailed imaging of the entire biliary tree ${ }^{5}$, the position of the drainage catheter and pre-operative assessment ${ }^{3,6}$, especially in recognition of residual stones following cholecystectomy and assessment of stenosis in patients with bilio-enteric 
anastomosis ${ }^{4}$. In contrast to ERCP, MRCP allows imaging of the extraductal structures through conventional $\mathrm{MR}$ images, and if necessary, intravenous paramagnetic contrast agent administration. Thus, it is an essential method for the assessment of tumor spread and staging 4,5,8 with comparable sensitivity and specificity to $\mathrm{CT}^{7}$. In the light of these findings, MRCP is an imaging technique with the potential to replace diagnostic ERCP in order to prevent ERCP-related complications.

The diagnostic accuracy of MRCP has been reported by several authors with an overall sensitivity of $60.5 \%$ $97.0 \%$, specificity of $75.0 \%-98.0 \%$, positive predictive value of $74.1 \%-89.0 \%$, and negative predictive value of $74.3 \%-98.0 \%{ }^{9-11}$. In the present study, these values were $85.0 \%, 50.0 \%, 89.4 \%$, and $40.0 \%$, respectively. The overall sensitivity and positive predictive values were similar to previous reports. Diagnostic success appears to be greater in some studies, and this might be explained by the larger patient samples or the possibility that the patient records may not have been maintained consecutively. Another reason for the difference in the results may be that the gold standard method of assessment has not been determined for some patients.

In a systematic review of 67 studies, Romagnuolo et al. ${ }^{12}$ noted that the overall sensitivity and specificity of MRCP in detecting the biliary obstruction were 95.0\% and $97.0 \%$, respectively. Sensitivity has been noted to be lower for stones $(92.0 \%)$ and malignant conditions (88.0\%). These differences might be due to the fasting state before the procedure or failure to detect stones because of common bile duct dilatation secondary to obstruction. Another significant cause for the discrepant findings is the inability of MRCP to detect stones $<4 \mathrm{~mm}$ in size. In addition, MRCP alone cannot differentiate malignant from benign obstruction.

In another systematic review, the results have been analyzed according to the underlying pathology. The median sensitivity and specificity for choledocholithiasis of 13 studies was $0.93 \%$ (range, $0.81 \%-1.00 \%$ ) and $0.94 \%$ (range, $0.83 \%-0.99 \%$ ), respectively. The sensitivity and specificity ranged from $81.0 \%$ to $94.4 \%$ and from
$92.0 \%$ to $100.0 \%$ for malignancy, respectively; and from $87.0 \%$ to $100.0 \%$ and from $91.0 \%$ to $100.0 \%$ for biliary dilatation, respectively. For obstruction, both sensitivity and specificity ranged from $91.0 \%$ to $100.0 \%$. The sensitivity for strictures was $100.0 \%$ and specificity ranged from $98.0 \%$ to $99.0 \%$. It was concluded that although there are some findings suggesting that MRCP is a sensitive method compared with diagnostic ERCP, the obtained values for malignancy compared with choledocholithiasis were somewhat lower ${ }^{13}$. In the present study, the sensitivity, specificity, and positive and negative predictive values of MRCP in detecting common bile duct dilatation were $70.0 \%, 77.2 \%, 73.6 \%$, and $73.9 \%$, respectively. Although our results appear to be mildly lower compared to other studies, the sensitivity value in the current study was higher than that reported by the study of Hurter et al. ${ }^{14}$ in which the sensitivity, specificity, and positive and negative predictive values of MRCP were $52.9 \%, 77.8 \%, 90.0 \%$, and $30.4 \%$, respectively. They attributed this result to the fact that MRCP was reported by a general radiologist, as in our unit.

We showed that the sensitivity, specificity, and positive and negative predictive values of MRCP in detecting strictures were $28.5 \%, 97.3 \%, 66.7 \%$, and $90.2 \%$, respectively. The sensitivity value in the present study was lower compared to other studies. The reason of the low sensitivity value might be the lower resolution of MRCP compared to direct cholangiography. Moreover, the small number of patients with definite strictures in the study population (7 of 51 patients) might be another reason.

In the study of Hurter et al. ${ }^{14}$, the sensitivity, specificity, and positive and negative predictive values of MRCP in detecting bile duct stones were $87.0 \%, 80.0 \%, 83.3 \%$, and $84.2 \%$, respectively, and to detect biliary tract strictures were $33.3 \%, 96.6 \%, 80.0 \%$, and $77.8 \%$, respectively. We have shown that the sensitivity, specificity, and positive and negative predictive values of MRCP in detecting bile duct stones were $71.4 \%, 88.8 \%, 83.3 \%$, and $80.0 \%$, respectively, which were similar to previous studies. It has been reported that the sensitivity of MRCP for detecting choledocholithiasis decreased with 
dilated bile duct $72.7 \%$ for a bile duct diameter $>10 \mathrm{~mm}$, and $88.9 \%$ for a bile duct diameter $\leq 10 \mathrm{~mm})^{15}$. Bile duct dilatation was present in 3 of 6 patients in whom we failed to demonstrate choledocholithiasis in the current study.

The difficulty of MRCP to differentiate stones $<5 \mathrm{~mm}$ in size was reported by Laokpessi et al. ${ }^{16}$. The MRCP results of 113 patients were compared to ERCP or intra-operative cholangiography in this study and stone diameter was shown to be $<3 \mathrm{~mm}$ in 7 of 8 false-negative results. It should also be noted that the clinical significance of small bile duct stones has been questioned since biliary stones are often present in feces of patients with multiple small gallbladder stones. It has been demonstrated in two prospective randomized studies that most of the bile duct stones resolve without causing any symptoms ${ }^{17,18}$. As in many previous studies, this may be the main reason for low sensitivity of MRCP in detecting choledocholithiasis in our study, as well. Other suggested reasons for false-positive MRCP results include a prominent ampulla, pneumobilia, ductal tortuosity, abnormal cystic duct configuration, or contraction of sphincter of Oddi ${ }^{19}$.

A nodular signal void was clearly observed in the MRCP images of 2 of our patients who were false-positive for stones. The ERCP was performed 5 and 6 days after MRCP in these patients and only bile mud was obser-

\section{Kaynaklar}

1. Bilbao MK, Dotter CT; Lee TG, et al. Complications of ERCP; a study of 10000 cases. Gastoenterology 1976; 70; 314-320.

2. Calvo MM, Bujanda $L$, Calderon $A$ et al. Role of magnetic resonance cholangiopancreatography in patients with suspected choledocholitiasis. Mayo Clin Proc 2002; 77: 422-8.

3. Manfredi R, Brizzi MG, Masselli G et al. Malignant biliary hilar stenosis: MR cholangiography compared with direct cholangiography. Radiol Med, 2001; 102: 48-54

4. Pavone $\mathrm{P}$, Laghi $\mathrm{A}$, Catalano $\mathrm{C}$ et al. $\mathrm{MRI}$ of the biliary and pancreatic ducts. Eur Radiol, 1999; 9: 1513-22.

5. Laing AD, Gibson RN. Magnetic resonance cholangiopancreatography. Australas Radiol, 1999; 43: 284-93. ved. These findings, together with the presence of papilledema during ERCP, suggested that the stones may have passed until the time of ERCP application. We may have a false-positive diagnosis in 1 patient due to bile flow-related signal void resembling a biliary stone.

Rapid improvements have been achieved in non-invasive imaging techniques of the biliary system. Although ERCP is still the primary method when diagnostic and therapeutic procedures are planned in patients with definite cholestasis, MRCP is increasingly being used in clinical practice as it is non-invasive diagnostic imaging method compared to ERCP. There is no optimal protocol defined for MRCP. Therefore, there are differences between the centers.

\section{Conclusion:}

In conclusion, MRCP is a non-invasive alternative method to ERCP and results of MRCP group have shown a high diagnostic accuracy solely for bile duct stones. Due to small number of patients, results for other biliary pathology were inconclusive.

MRCP has gaining wider use and has the potential to replace diagnostic ERCP Increase in experience of MRCP examination and studies with larger series may provide improvement in results; thus, increase in diagnostic success may be established.

6. Little AF, Smith PJ, Lee WK, Hennessy OF, Desmond PV, Banting SW, et al. Imaging of the normal and abnormal pancreaticobiliary system with single-shot MR cholangiopancreatography: a pictorial review. Australas Radiol 1999;/43:/427_34.

7. Lincender L, Sadagic E, Vrcic D et al. Magnetic resonance cholangiography in patients with bile duct obstruction. Radiol Oncol, 2000; 34: 319-24.

8. Barish MA, Yucel EK, Ferrucci JT. Magnetic resonance cholangiopancreatography. N Engl J Med, 1999; 341: 258-64

9. Soto JA, Barish MA, Yucel EK, Siegenberg D, Ferrucci JT, Chuttani R. Magnetic resonance cholangiography: comparison with endoscopic retrograde cholangiopancreatography. Gastroenterol- 
ogy 1996; 110: 589-97.

10. Varghese JC, Farrell MA, Courtney G, et al. A prospective comparison of magnetic resonance cholangiopancreatography with endoscopic retrograde cholangiopancreatography in the evaluation of patients with suspected biliary tract disease. Clin Radiol 1999; 54: 513-520.

11. Taylor ACF, Little AF. Prospective assessment of MRCP for noninvasive imaging of the biliary tree. Gastrointest Endosc 2002; 55(1): 17-22.

12. Romagnuolo J, Bardou M, Rahme E, et al. Magnetic resonance cholangiopancreatography: a meta-analysis of test performance in suspected biliary disease. Ann Intern Med 2003; 139: 547-557.

13. Kaltenthaler E, Bravo Vergel $Y$, Chilcott J, et al. A systematic review and economic evaluation of magnetic resonance cholangiopancreatography compared with diagnostic endoscopic retrograde cholangiopancreatography. Executive summary. Health Technology Assessment 2004; 8(10): 1-6.

14. Hurter D, Vries CD, Potgieter PH, Barry R, Botha F J H, Joubert G. Accuracy of MRCP compared with ERCP in the diagnosis of bile duct disorders SA Journal Of Radiology 2008; 14-22.

15. Moon JH, Cho YD, Cha SW, et al. The detection of bile duct stones in suspected biliary pancreatitis: Comparison of MRCP, ERCP, and intraductal US. Am J Gastroenterol 2005; 100: 10511057.

16. Laokpessi A, Bouillet P, Sautereau D, Cessot F, Desport J-C, Sidaner A, Pillegand B. Value of magnetic resonance cholangiography in the preoperative diagnosis of common bile duct stones. Am J Gastroenterol 2001; 96:2354-2359.

17. Hauer-Jensen M, Karesen R, Nygaard K, Solheim K, Amlie E, Havig O, Viddal KO. Consequences of routine perioperative cholangiography during cholecystectomy for gallstone disease - a prospective randomized study. World J Surg 1986; 10:996-1002.

18. Murison MSC, Gartell PC, McGinn FP. Does selective preoperative cholangiography result in missed common bile duct stones? [Abstract]. Br J Surg 1989; 76:1343.

19. Fulcher AS, Turner MA. Pitfalls of MR cholangiopancreatography. J Comput Assist Tomogr 1998; 22:845-850. 